\title{
Uit die geskiedenis van die "Corps Staatsartillerie" van die Zuid-Afrikaansche Republiek
}

\section{Kol dr Jan Ploeger*}

The author of this article has put together diverse military-historical notes on the "Corps Staatsartillerie" of the "Zuid-Afrikaansche Republiek" and has dedicated his article to the memory of the late brig Willem Otto, in life Director of the Military Information Bureau.

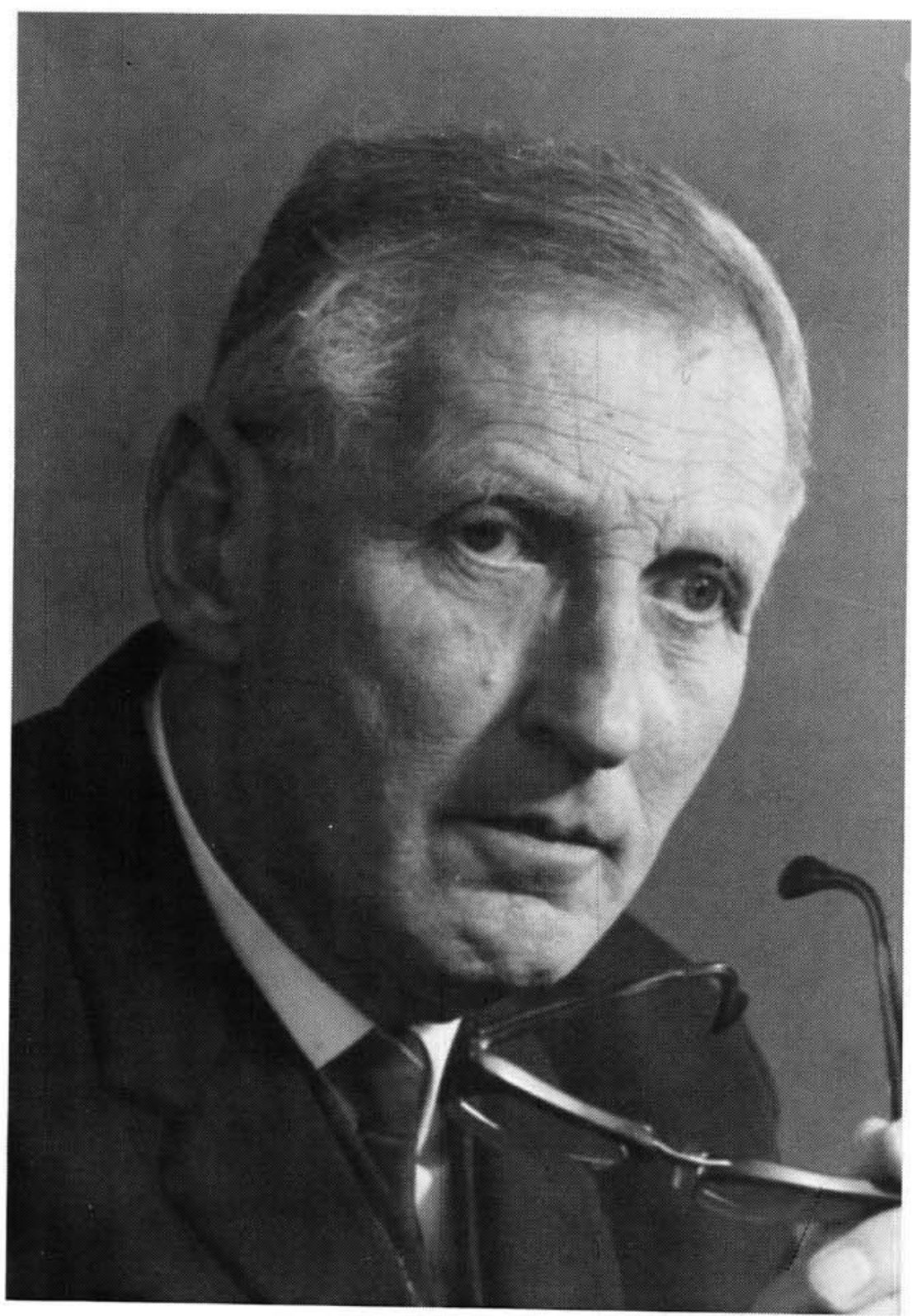

Kol dr Jan Ploeger 
Die volgende uiteenlopende militêr-historiese aantekeninge is opgedra aan die nagedagtenis van wyle brig Willem Otto, in lewe Direkteur Militêre Informasieburo.

Hy sal soos tereg in Militaria 15/1, 1985, opgemerk is, onthou word as 'n offisier wat sy rang met besondere waardigheid gedra en sy taak nougeset en op 'n uiters verantwoordelike wyse uitgevoer het.

Uit eie ervaring weet die skrywer van hierdie besondere huldeblyk dat brig Otto nie alleen die studie van ons militêre geskiedenis met liefde, vaardigheid en toewyding beoefen het nie, maar terselfdertyd alles in sy vermoë gedoen het om, in woord en geskrif, ander bewus te maak van ons ryk erfenis op dié besondere terrein van ons verlede.

Mag dié voorbeeld wat deur hom gegee is ook in die toekoms deurwerk, veelvuldige vrugte afwerp en terselfdertyd ons kennis van, en ons liefde vir die spesifieke aspek van ons verlede vermeerder, verdiep en versterk! So 'n doelbewuste strewe lei onder meer na die verstewiging van ons militêre tradisie.

\section{Die agtergrond}

In sy lesenswaardige oorsig oor die militêre geskiedenis van Pretoria het die bekende historikus prof dr F.J. du Toit Spies op die stigting van die oudste artilleriekorps in die Transvaalse Hoofstad (1873), die verdwyning van dié eenheid tydens die eerste anneksasie (1877) en die herrysenis van ' $n$ republikeinse artilleriekorps in 1881 gewys. ${ }^{1} \mathrm{Na}$ verskillende naamsveranderings en reorganisies het die eenheid in die tagtigerjare 'n artilleriekorps in die ware betekenis van die woord geword deurdat die tydelik bestaande samevoeging met die berede polisie verbreek is. In hierdie dikwels moeilike vormingsjare van die korps het kmdt Henning Petrus Nicolaas Pretorius (1844-1897) hom beywer om opbouende werk te verrig deur onder meer ' $n$ afdeling veldtelegrafie aan die eenheid toe te voeg, deur reëlings met betrekking tot die skoolonderrig van artilleriste te tref en om jong belowende Transvalers na die buiteland te stuur om daar, ooreenkomstig die destydse krygskundige beginsels, opgelei te word. ${ }^{2}$ In 1894 en 1895 het daar aldus prof dr F.J. du Toit Spies, nog nie veel van die beplande reorganisasie van die korps tereg gekom nie en teen die einde van 1895, toe die Jameson inval die rus in die republiek onverwags en wreed versteur het, het die korps uit nege offisiere en ' $n$ sewentig manskappe bestaan van wie 'n aantal tussen Kersfees en Nuwejaar met verlof was. Op Nuwejaarsdag 1896 is die uitgedunde geledere van die korpslede onder meer deur die Middelburgse Kommando onder kmdt Stephanus Petrus Erasmus Trichardt (1840-1907) versterk. Sonder om verder op die reeds genoemde gebeurtenis en die verydeling van die planne van die invallers in te gaan, word hier slegs vermeld dat die republikeinse regering deeglik besef het dat die Staatsartilleriekorps onder meer onmiddellik versterk en beter bewapen moes word. Ook is planne beraam om forte rondom Pretoria te bou. ${ }^{3}$

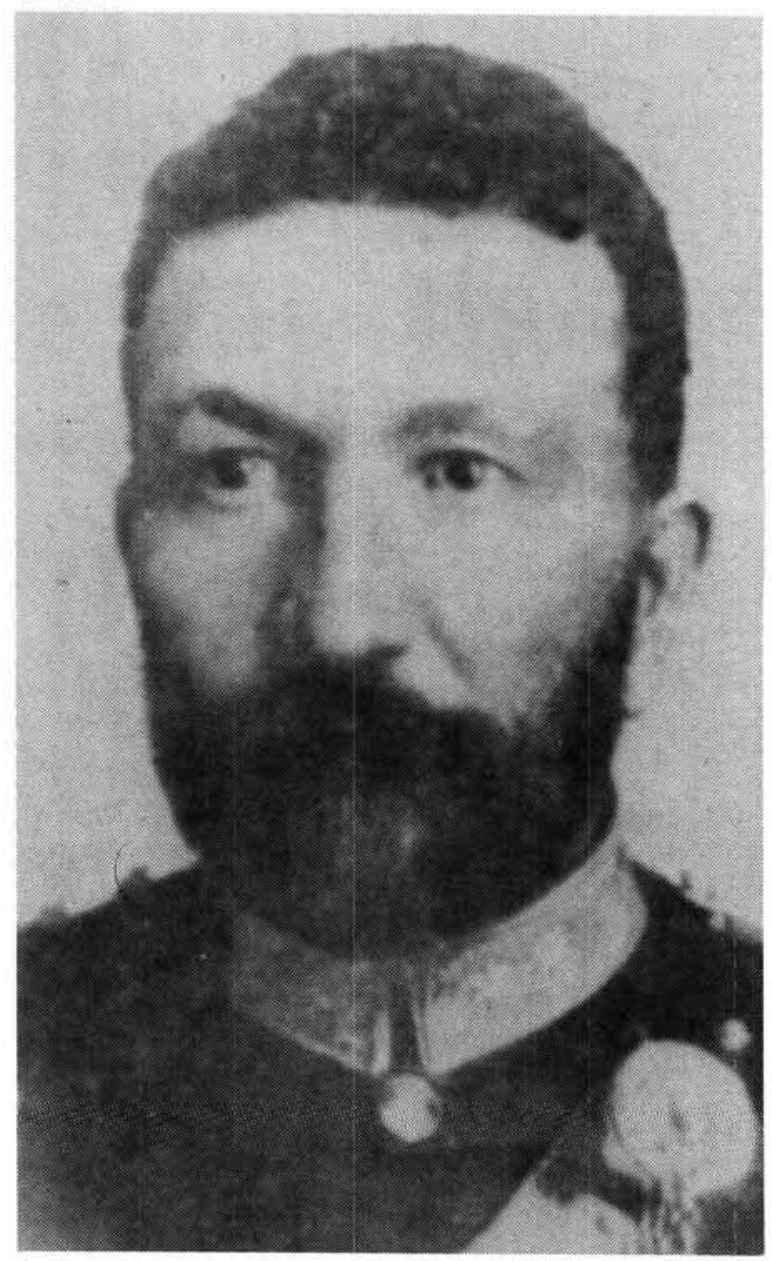

Kmdt S.P.E. Trichardt 
Reeds op 14.2.1896 het die Uitvoerende Raad onder meer besluit om die bevelvoering van die korps aan 'n "overste-commandant" maw 'n luitenant-kolonel, toe te vertrou. Hierdie offisier is deur ' $n$ luitenant adjudant en 'n skrywer, maw 'n klerk, bygestaan. Verder is tydens dieselfde raadsvergadering besluit om die korps in twee afdelings, tewete ' $n$ afdeling rydende artillerie (RA) en ' $n$ afdeling bergartillerie (BA) te verdeel. Elkeen van die afdelings sou onder 'n kaptein ressorteer, terwyl die RA uit ' $n$ eerste luitenant, drie tweede luitenante, 'n adjudant-onderoffisier, 'n opperwagmeester, ' $n$ foerier, 14 wagmeesters, 16 korporaals, ses trompetblasers en 200 manskappe sou bestaan.

Die sterkte van die BA is kragtens dieselfde besluit op ' $n$ drietal tweede luitenante, ' $n$ adjudant-onderoffisier, 'n opperwagmeester, 'n foerier, ses wagmeesters, agt korporaals, vier trompetblasers en 100 manskappe vasgestel. ${ }^{4}$

Op 31.3.1896 het die sterkte van die korps, met inbegrip van veldtelegrafiste en offisiere, reeds 416 bedra en het die Uitvoerende Raad besluit om die sterkte na 400 terug te voer ${ }^{5}$

Op 2.10.1896 is It-kol H.P.N. Pretorius deur die volgende offisiere bygestaan, maj P.E. Erasmus, kapt J.F. Wolmarans, kapt Bosman, waarn kapt P.J. van der Merwe, 1/lt adj T. Kroon, 1/lt J.L. Pretorius, 1/tt A. Carlblom, offisier van gesondheid dr J.L. Laxton, 1/lt P.C. Paff (veldtelegrafie), kapelmeester J.M. Maggs, 2/lt adj Baay, 2/lt kwartiermeester E.B.C. Hoffman en 2/lt M.J. de Jager. ${ }^{6}$

Soos bekend het It-kol H.P.N. Pretorius op 25.1.1897 onverwags op die plaas Abrahamschoot, distrik Albany, in Kaapland heengegaan. Die afsterwe van die "vader van die Staatsartillerie" is allerweë betreur en ' $n$ opvolger moes gevind word om die bestaande hoë peil van die korps te handhaaf en die slegs gedeeltelik uitgevoerde reorganisasie-, uitbreidings- en opknappingsplanne verder ooreenkomstig die riglyne van die regering en genl P.J. Joubert, kommandant-generaal van die republiek se verdedigingsmag, uit te voer.

\section{Lt kol S.P.E. Trichardt volg It-kol H.P.N. Pretorius op}

In sy herinneringe het It-kol S.P.E. Trichardt reeds in 1898, met medewerking van It Thomas Kroon besonderhede oor sy lewensloop begin aanteken en in 1903 is hierdie werksaamhede voortgesit. ${ }^{7}$

In hierdie aantekeninge is die heengaan van Itkol Pretorius as ' $n$ groot ramp vir die korps bestempel en onder meer beklemtoon dat die heengegane deur die burgers hoog geag en deur die korpslede as ' $n$ vader bemin is. ${ }^{8}$

Met betrekking tot die opvolging het It-kol Trichardt beklemtoon dat die meeste offisiere van die korps jonk was en dat die voorkeur aan 'n ouer en ervare opvolger van It-kol Pretorius gegee is. Heelwat bekende persone, wat ook op krygskundige gebied hulle spore verdien het, het hulle dienste aangebied en eindelik het, aldus It-kol Trichardt, die keuse op hom geval. Burgers uit die distrik Middelburg waar Trichardt naturelle-kommissaris en distrikskommandant was, het hom probeer oorreed om die benoeming nie aan te neem nie, maar Trichardt het gemeen om die belang van die land te dien deur die hoogs gewigtige pos te aanvaar. Geldelike voordeel het geen rol in verband met sy besluitvorming gespeel nie en op 21.7.1897 is hy deur genl P.J. Joubert ingesweer en daarna aan die korps bekend gestel. ${ }^{9}$

Dit is interessant om Trichardt se weergawe van die gebeurtenisse wat tot sy benoeming gelei het, met die nog aanwesige dokumentasie onder die stukke van die Departement van die Staatssekretaris (SS) te vergelyk. ${ }^{10}$ Uit die laasgenoemde gegewens word dit onder meer duidelik dat Trichardt se weergawe van die toedrag van sake eenvoudiger is as wat in werklikheid die geval was en dat sy vermelding dat "Daar de officieren der artillerie meestallen jonge menschen waren, zag men liever aan het hoofd van het corps een man van rypere leeftyd en ervaring geplaatst" aanleiding tot diepgaande meningsverskille sou gee. ${ }^{11}$

Lt kol Pretorius het op 25.1.1897 die tydelike met die ewige verwissel en op 1.2.1897 het kmdt S.P.E. Trichardt aansoek om die vakante pos as bevelhebber van die artilleriekorps gedoen. Vyf dae later het genl P.J. Joubert aan staatspresident Kruger geskryf dat hy hom versoek om kmdt Trichardt as It-kol Pretorius se opvolger aan te stel omdat eersgenoemde se aanstelling "onder de omstandigheden, een aanwinst voor ons Artillerie Corps zal wezen." ${ }^{12}$

Behalwe kmdt Trichardt het krygskommissaris W.C. Meyer en vk D.J. Schoeman (distrik Lydenburg), onderskeidelik op 5.2.1897 en 15.2.1897 
aansoek om die vakante pos gedoen, terwyl 'n sekere J.J. Ferreira sy ongedateerde aansoek later teruggetrek het. ${ }^{13}$

Vermoedelik reeds voordat krygskommissaris Meyer se aansoek ontvang is, het genl Joubert reeds sy genoemde versoek aan die Staatspresident gerig. Nie alleen het hy geen latere aansoeke afgewag nie, maar deur sy aanbeveling ook op ' $n$ botsing met die diensdoende offisiere van die korps afgestuur. Al die offisiere het op 4.2.1897 skriftelik hulle begeerte teenoor die Kommandant-generaal te kenne gegee dat die bestaande vakature so spoedig moontlik gevul word en die geadresseerde se aandag op Art 38 van Wet nr 1, 1896 gevestig. In die bepaling is, volgens die ondertekenaars van die genoemde skrywe, duidelik die opvolger van die oorledene aangewys. Op grond daarvan is genl Joubert versoek om "de op deze betrekking recht hebbene" by die regering aan te beveel en vir benoeming voor te dra. Al die diensdoende offisiere van die korps het hierdie skrywe met hulle handtekenings bekragtig en op 4.3.1897 het Staatsprokureur dr H.J. Coster, wie se adres op 3.3.1897 deur Staatssekretaris dr W.J. Leyds gevra is, op die betrokke lêer aangeteken dat daar heeltemal in ooreenstemming met Art 36, 37 en 38 van Wet nr 1, 1896 maw die wet in verband met die Staatsartillerie, gehandel word. "Wanneer de officier, die het naast op den commandant in rang volgt, tot die post wordt bevorderd." ${ }^{\text {14 }}$

Die volgende stap was dat die regering hom op 9.3.1897 met die staatsprokureur vereenselwig het en vir oorweging aan die Kommandantgeneraal voorgelê het om maj P.E. Erasmus "als troef voorlopig aan te stellen." ${ }^{15}$ Op dieselfde dag het maj Erasmus aansoek om die vakante pos gedoen en verklaar dat hy sy rede aan die Kommandant-generaal sou meedeel hoekom hy, ofskoon hy vroeër aan die Kommandantgeneraal gesê het dat hy die vakante pos nie sou aanvaar nie, nou wel bereid was om dit te doen. ${ }^{16}$

Voordat die regering hom dus op grond van die genoemde wet en die advies van die Staatsprokureur nie met genl Joubert se aanbeveling met betrekking tot kmdt S.P.E. Trichardt vereenselwig het nie, het genl Joubert op 22.2.1897 op die betrokke lêer aangeteken dat hy Wet $\mathrm{nr} 1$, 1896, wel oorweeg het, maar van gedagte was dat die diensdoende offisiere te jonk was. Gevolglik het hy nogmaals op kmdt Trichardt se spoedige benoeming aangedring. ${ }^{17}$

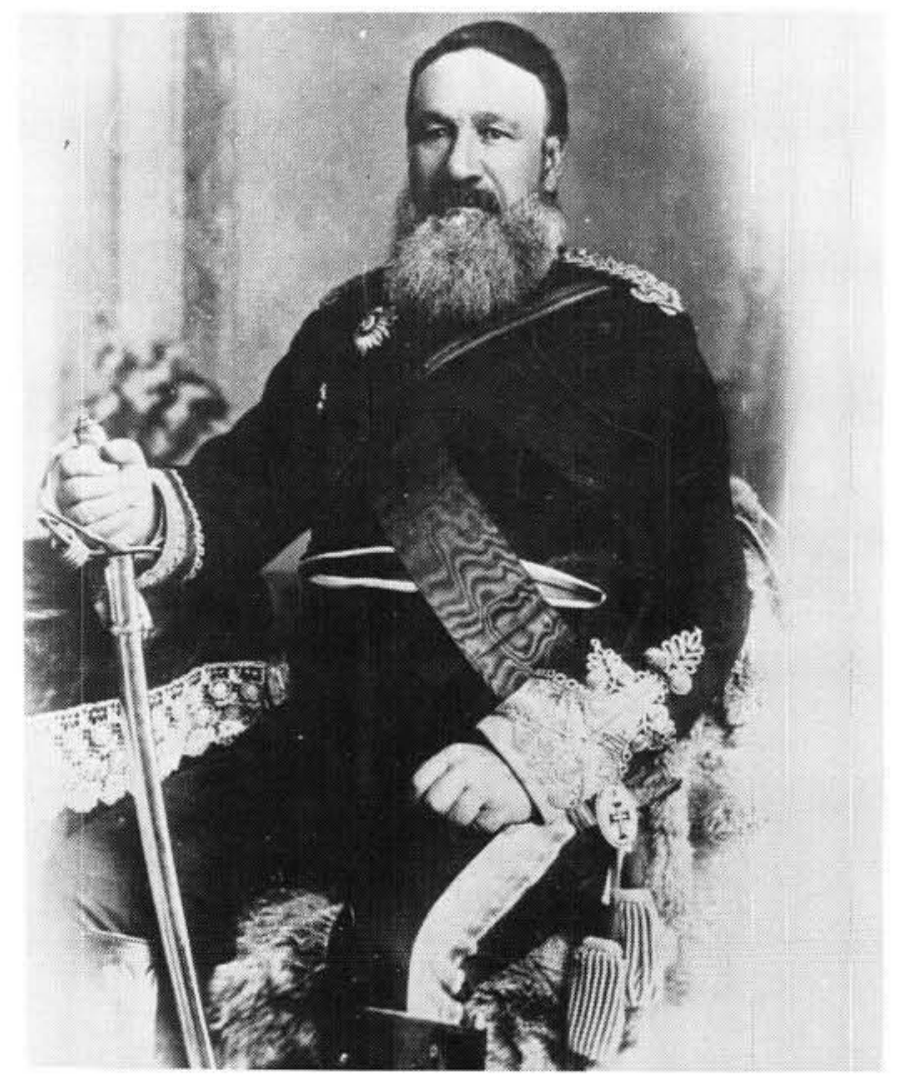

Genl P.J. Joubert 
Op 24.3.1897 het die Kommandant-generaal, in 'n soortgelyke aantekening, verklaar dat hy maj Erasmus se aansoek nie kon steun of aanbeveel nie en het hy daaraan toegevoeg dat die majoor se applikasie op hom, maw die majoor, afgedwing was. Genl Joubert het hom, op grond van die uitspraak, op maj Erasmus se vroeëre verklaring beroep dat hy nie vir die vakante pos in aanmerking wou kom nie, "te meer omdat daardoor eene ongewenschte onnoodige promotie bevorderd zou worden." Genl Joubert het die sienswyse as verstandig en verstaanbaar beskou, maar kon hom nie met die nuwe, veranderde koers vereenselwig nie en het aan sy besware toegevoeg: "Als zaken in het kamp loopen zooals ze niet moeten loopen, dan is het, omdat aan myn gezegde Minute niet is of wordt voldaan, en kan ik niet die verantwoordelykheid ervan dragen." ${ }^{18}$

Voorlopig het daar, van die kant van die kantoor van die Staatsekretaris geen reaksie op die genoemde blyke van verskil van mening tussen die regering se beleid en die Kommandant-generaal in die vorm van korrespondensie gevolg nie. Dit sou tot 22.4.1897 duur voordat genl Joubert die volgende vraag op skrif sou stel en aan die kantoor van die Staatsekretaris sou vra: "Hoe lang moet ik op deze aanstelling wachten? Onder de tegenwoordige omstandigheden van het land kunnen zaken als deze niet overstaan." ${ }^{19}$

\section{Maj P.E. Erasmus}

Die reeds herhaaldelik genoemde maj P.E. Erasmus was ' $n$ seun van naturellekommissaris Abel Erasmus, van Lydenburg. Hy het vanaf sy negentiende tot sy twintigste jaar, maw in 1889 en ' $n$ deel van 1890, die Christelike skool in Nymegen, Nederland, besoek om die Nederlandse taal te leer. Van September 1890 tot Junie 1892 het 'hy by die veldartillerie in Amersfoort, Nederland, diens gedoen en onder meer aan praktiese artillerie-oefeninge in die kamp by Oldebroek deelgeneem. Van September 1892 tot Augustus 1893 het hy aan die Koninklike Militêre Akademie te Breda, Nederland, sy studie voortgesit. In die loop van die laasgenoemde maand het hy na Duitsland vertrek om kennis van die Duitse taal op te doen om daarna, met dieselfde doel voor oë, 'n tydjie in Engeland deur te bring. Al hierdie besonderhede het Erasmus op 21.10.1893 aan genl P.J. Joubert verstrek en aan die Kommandant-generaal gevra of hy in April 1894 in die rang van 'n tweede luitenant, by die Transvaalse Lydende
Artillerie kon aansluit. ${ }^{20}$ Vermoedelik het genl Joubert goedgunstig oor hierdie versoek beskik want in die loop van 1894 is Erasmus, na 'n eksamen, op 'n proeftyd van nege maande, in die rang van 'n eerste luitenant aangestel. In 1896 het sy bevordering na kaptein en vervolgens na majoor gevolg. ${ }^{21}$ Op 27.4.1896 het kapt P.E. Erasmus as een van die getuies in die saak teen die Rand Reformers opgetree. ${ }^{22}$

\section{Die Kommandant-generaal hou voet by stuk}

Op sy vraag van 22.4.1897 het genl Joubert van die kantoor van die Staatssekretaris verneem dat, ooreenkomstig hoofstuk IV van Wet $\mathrm{Nr} 1$, 1895, aanstellings en bevorderings in die korps uit die geledere van die bestaande korpsoffisiere moes geskied. Veral met verwysing na Art 38 van die genoemde Wet het die regering, as 'n oplossing van die vraagstuk, aan die Kommandant-generaal in oorweging gegee om maj Erasmus vir ' $n$ tydperk van ses maande as bevelhebber van die Staatsartillerie aan te stel. $\mathrm{Na}$ die verstryking van die proeftyd kon die Kommandant-generaal dan ' $n$ verslag aan die regering voorlê.

Op 15.5.1897 het genl Joubert nogmaals skriftelik beklemtoon dat hy hom nie met die plan van die regering kon vereenselwig om maj Erasmus ses maande aan te stel nie. Aan hierdie herbevestiging van sy reeds bekende standpunt het die Kommandant-generaal toegevoeg dat hy van tyd tot tyd heelwat verdriet en moeite in verband met die betwiste aangeleentheid ondervind het. Volgens sy mening was dit duidelik dat planne in ongenoemde kringe beraam is om hom tot ' $n$ val te bring.

Liewers as om só verder te sukkel sonder om 'n begeerde helper te kan bekom, het die Kommandant-generaal verkies om "liever het Kamp en de Artillerie, met alles wat daaraan verbonden is, geheel van my af te trekken en my van alle verantwoordelykheid daarvan te ontslaan, terwyl ik anders door de omstandighede gedwongen zal worden, ter wille van myn eigen behoud voor een ander plaats te maken". ${ }^{23}$

Uit hierdie aanhaling blyk dit duidelik dat die Kommandant-generaal nie van plan was om vir die beleid te swig wat die regering onder meer op grond van die Staatsprokureur se advies aan hom voorgelê het nie. Genl Joubert sou liewers sy bedanking aan die regering voorlê en het 
nogmaals daarop aangedring dat die regering die betwiste aangeleentheid spoedig sou afhandel. ${ }^{24}$

In sy antwoord het die regering die Kommandant-generaal gevra om nie alleen met maj Erasmus nie, maar met al die artillerie-offisiere, 'n bespreking oor die aangeleentheid te hou. Tydens dié gedagtewisseling moes ' $n$ reëling gevind word waardeur die moontlikheid vir die Staatspresident geskep sou word om ooreenkomstig genl Joubert se standpunt te handel. Indien so ' $n$ reëling nie getref kon word nie, dan sou die Staatspresident verplig wees om ooreenkomstig die bepalings van Wet $\mathrm{nr} 1,1896$, op te tree.

Op 18.5.1897 het genl Joubert geantwoord dat hy die offisiere reeds vroeër ontmoet en hulle omtrent sy sienswyse ingelig het, nadat hy van maj Erasmus verneem het dat hy nie vir die vakante pos in aanmerking wou kom nie. By dié geleentheid het kapt J.F. Wolmarans en It J.M.A. Wolmarans hulle ewewel teen genl Joubert se voorstel verklaar om kmdt S.P.E. Trichardt aan te stel en die houding ook daarna bly huldig. Op grond van hierdie teenstand het die Kommandant-generaal dan ook sy antwoord op die regering se versoek toegevoeg. "Ik zie dan ook niet in wat een andere byeenkomst met die Officieren zal helpen, te meer niet na het geen door Zy Edele den Staatspresident in een onderhoud aan majoor Erasmus gezegd werd." 25

Uit hierdie antwoord word dit duidelik dat die voorstel van die regering die bestaande geskil nie opgelos het nie. Genl Joubert het weereens daarop aangedring dat die regering aan sy reeds vroeër gestelde versoek moet voldoen. Uit die aangehaalde antwoord van genl Joubert word dit verder duidelik dat die bestaande korrespondensie nie ' $n$ volledige beeld van die ver- loop van die geskil weergee nie. Daar is ongetwyfeld heelwat gepraat. En dit geld vermoedelik ook nadat die Kommandant-generaal se skriftelike antwoord van 18.5.1897 deur die waarnemende Staatsekretaris ontvang is. Op 16.6.1897 het hierdie hoofamptenaar op las van die Staatspresident aan genl Joubert meegedeel dat al die offisiere van die korps skriftelik afstand moes doen van hulle regte in verband met bevordering en moontlike bevelvoering. Slegs dan kon die Staatspresident wat "staat onder de Wet, heeft die te gehoorzamen en moet zich daaraan houden" ooreenkomstig genl Joubert se begeerte optrede. ${ }^{26}$

Drie dae nadat hierdie opdrag aan genl Joubert gestuur is, het die Kommandant-generaal 'n skrywe van maj Erasmus ontvang waarin laasgenoemde meegedeel het dat hy reeds vyf maande waarnemende bevelhebber van die Staatsartillerie was en dat die verantwoordelikheid groot was. Aangesien die Staatsartillerie en die burgerkommandos in oorlogstyd moes saamwerk en daar 'n goeie verstandhouding tussen die twee dele van die krygsmag moes bestaan, het maj Erasmus besluit om sy aansoek in verband met die bestaande vakature terug te trek. Aan hierdie mededeling het hy toegevoeg dat hy liewer sou sien "dat een der oude Burgercommandanten, die eene goede bemiddeling tusschen ons en de Burgermacht kan zyn, aan te stellen." 27

Volgens maj Erasmus het hy persoonlik besef dat hy nie die aangewese persoon as bevelhebber van die korps was nie. Bygevoeg het hy afstand van sy aansprake gedoen. "In't belang van onze strydmacht in't algemeen en van't Corps Staats Artillerie in't byzonder en meen myne gehechtheid aan't dierbaar Vaderland en't Corps Staats Artillerie hiermede te kennen te geven."28

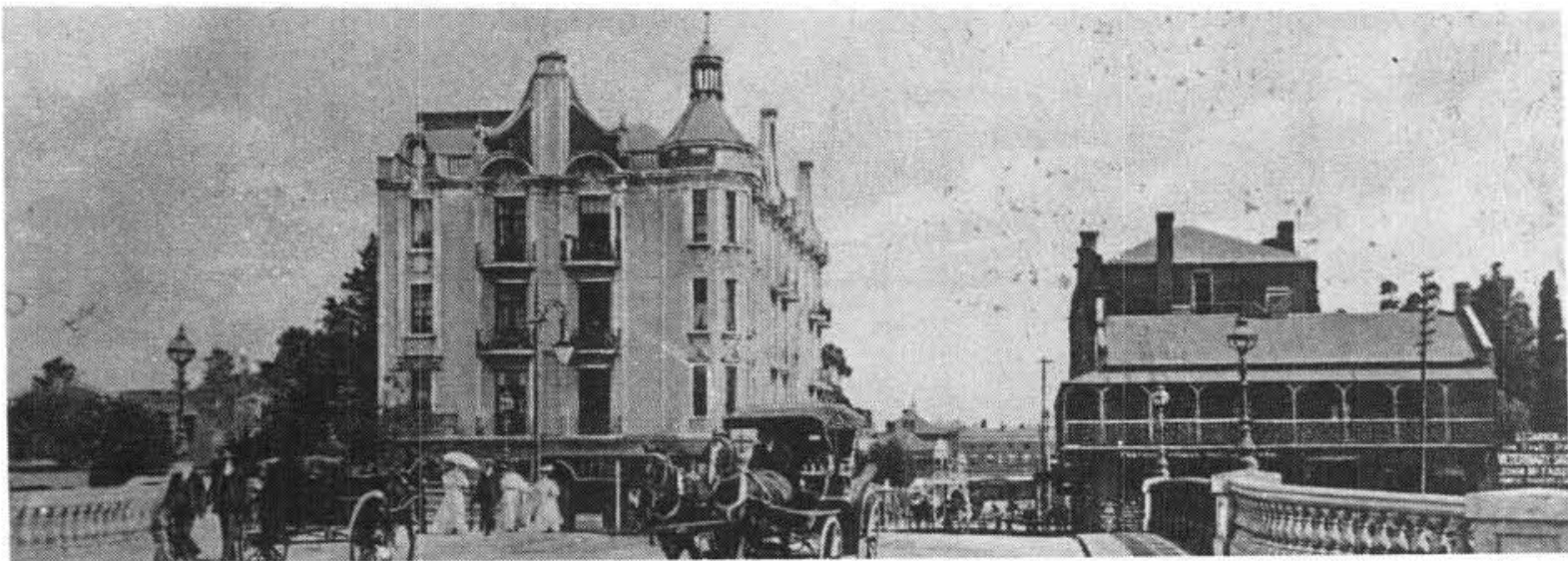

Genl Piet Joubert besoek die perseel van die nuwe artilleriekamp tydens die bou daarvan. 
Op dieselfde dag het die ander offisiere van die korps skriftelik afstand gedoen van hulle reeds genoemde regte wat in Art 38 van Wet $\mathrm{nr} 1$, 1896 omskryf was. Nou was die pad oop om kmdt Trichardt se aanstelling as bevelhebber van die korps Staatsartillerie, in die rang van luitenant-kolonel, op 23.6.1897 te onderteken. Die nuwe bevelhebber het op 26.6.1897 diens aanvaar en op 14.7.1897 is die gebruiklike eed deur hom afgelê.. ${ }^{29}$

Hierdie datum is aan twyfel onderhewig. Volgens Trichardt se eie weergawe van sy lewensloop en De Volksstem van 26.7.1897 is hy op 21.7.1897 deur genl P.J. Joubert ingesweer en het hy die volgende eed afgelê om vervolgens aan die korps voorgestel te word: "Ik beloof en zweer plechtig dat ik getrouw zal zyn aan het Volk der Zuid-Afrikaansche Republiek in myne betrekking als Luitenant-kolonel der Staats Artillerie, van niemand eenige gift of gunst zal aannemen, wanneer ik vermoeden kan dat deze gift of gunst gedaan of bewezen zou worden met het oogmerk om van my een besluit ten voordeele van den begunstiger of gever te gewinnen; dat ik my gedragen zal overeenkomstig de wetten dezer Republiek. Zoo waarlyk helpe my God Almachtig!"30

Aan die aanstelling van It-kol S.P.E. Trichardt as bevelhebber (kommandant) van die korps Staatsartillerie het dus aanmerklik meer vooraf gegaan as in Trichardt se herinnering aangeteken is.

Weliswaar is op p 85 van die gedrukte herinneringe aangeteken: "Daar de officieren der artillerie meest allen jonge menschen ware, zag men liever aan het hoofd van het corps een man van rypere leeftyd en ervaring geplaatst. Vele wel bekende personen, die ook op krygskundig gebied hunne sporen verdiend hadden, stelden zich candidaat en viel eindelyk de keus op my." ${ }^{\text {31 }}$

\section{Sekere gevolgtrekkings}

Uit bestaande aanhalings en uit die geraadpleegde en verwerkte dokumentasie kom sekere verskille aan die lig. Genl Joubert het, reeds voordat al die aansoeke in verband met die opvolging van wyle It-kol H.P.N. Pretorius ontvang is, kmdt S.P.E. Trichardt aanbeveel en sy kandidatuur bly ondersteun. Die argument wat hy in verband hiermee genoem het, was dat die wetlike aanspraakmaker ooreenkomstig die bepalings van die wet op die Staatsartillerie (maj
P.E. Erasmus) te jonk was. Hierdie rede is deur genl Joubert as deurslaggewend beskou om die bepalings van Wet $\mathrm{nr} 1,1896$, te verontagsaam. Staatspresident Kruger sowel as onder meer Staatsprokureur dr H.J. Coster was daarvan oortuig dat die opvolgingsvraagstuk slegs op een wyse, te wete ooreenkomstig die bepalings van die genoemde Wet, opgelos kon word. 'n Dooie punt is bereik wat uiteindelik opgelos is deurdat, op aanrade van President Kruger, die offisiere van die korps aangesê moes word om hulle bevorderings- en opvolgingsregte prys te gee waaroor hulle op grond van die herhaaldelik genoemde wet beskik het. Nadat maj Erasmus sy tydelike pos as bevelhebber neergelê het, het die offisiere aan die president se begeerte voldoen en kon die benoeming van It-kol Trichardt plaasvind. Wat altyd vermoedelik wel onbekend sal bly, was wat mondelings, agter die skerms plaasgevind het, maar dit is duidelik dat, sowel deur genl Joubert as deur Staatspresident Kruger sekere waarborge van Wet $\mathrm{nr} 1$, 1896 , nie onaangetas gelaat is nie.

Die Corps Staats Artillerie wat onder die opperbevel van die Kommandant-generaal was, is deur ;n "Overste Commandant" of 'n "Luitenantkolonel" aangevoer en was uit die volgende afdeling saamgestel: Die afdeling Artillerie, bestaande uit Rydende Artillerie (RA), Bergartillerie (BA) en Vestingartillerie (VA); die Veldtelegrafie (VT), die "Intendancedienst" (kommissariaat) die musiekkorps, die geneeskundige diens, die afdeling onderwys en die smedery- en bankwerkafdeling $^{32}$

\section{Besonderhede met betrekking tot die onderwys aan artilleriste}

Hierdie gedeelte van die bydrae maak geensins aanspraak op volledigheid nie, maar die skrywer wil graag die lesers se aandag vestig op 'n onderwerp waaromtrent daar nog geen afgeronde navorsing verrig en die resultate daarvan gepubliseer is nie.

Uit die Uitvoerende Raad se besluit $\mathrm{nr} 736$, van 26.11.1890 blyk dit dat die Staatsartillerie se onderwyser, ' $n$ sekere Susan, weer aangestel is. Uit hierdie vermelding kan afgelei word dat die genoemde onderwyser reeds voor die datum skoolonderrig aan artilleriste gegee het. In Wet $\mathrm{nr} 1,1896$, is onder meer bepaal dat artilleriste in dieselfde vakke onderrig sou word wat in die Transvaalse onderwyswet genoem is. Inspekteurs sou toesig oor die besondere onderwys 
hou en hulle bevindings aan die Kommandantgeneraal voorlê, terwyl in laasgenoemde se jaarverslag besonderhede in bogenoemde verband verskaf sou word. ${ }^{33}$

Op 21.3.1896 het kapt J.F. Wolmarans met verwysing na die uitbreiding van die korps en die bou van 'n nuwe klaskamer vir manskappe goedkeuring gevra om vier banke van ses voet, vier van vier voet en vier van tien voet teen ' $n$ totale koste van ongeveer £17:10:0 aan te koop. Hierdie versoek is goedgekeur. ${ }^{34}$

Ofskoon daar dus 'n nuwe klaskamer gebou en van skoolbanke voorsien is, het maj Erasmus hom in die korps se jaarverslag oor 1896 soos volg oor die onderwys uitgespreek: "Wat het onderwys betreft dat laat veel te wenschen over. Sedert de in werking treding van wet 1/96 is er aan het onderwys zoo goed als niets gedaan daar de wet bepaald, dat de onderwyzers niet tot het Corps behooren." ${ }^{35}$

Weliswaar het maj Erasmus alles in sy vermoë gedoen om 'n onderwyser aangestel te kry, maar die pogings is voorlopig nie met welslae bekroon nie. Dit was ook die geval in verband met die opleiding van toekomstige offisiere wat uit die geledere van die burgers afkomstig was. ${ }^{36}$

Die skoolonderrig van manskappe en toekomstige offisiere het volgens bogenoemde verslag dus stilgestaan.

In 1897 was die Nederlandse onderwyse L.L. Steen, wat in April 1896 op Pretoria aangekom het, bereid om as onderwyser in die artilleriekamp te werk. ${ }^{37}$ Aan die begin van Oktober 1897 het die nuwe onderwyser ' $n$ lys van benodigdhede, soos lees-, reken- en taal- boekies, leie, penne, potlode, kryt, kaarte, penhouers en griffels, aan It-kol S.P.E. Trichardt voorgelê. Hierdie benodigdhede was as aanvullings van aanwesige voorrade bedoel. Omstreeks dieselfde tyd het die Kommandant-generaal 'n plek in die kamp aangewys wat as 'n skool ingerig kon word sodat die aangestelde onderwyser kon begin onderwys gee. ${ }^{38}$

Die kampskool is op 13.10.1879 deur die Kommandant-generaal geopen en in die loop van sy toespraak het genl Joubert onder meer verklaar dat die onderwys van nou af sonder onderbreking, en onder leiding van L.L. Steen, sou voortgaan. ${ }^{39}$ Voordat hy oor voldoende leermiddels beskik het, het Steen die manskappe - oor- eenkomstig hulle peil van ontwikkeling - in standerds ingedeel. Later, nadat die forte Wonderboom, Schanskop, Klapperkop en Daspoortrand voltooi en beman en vier gesertifiseerde onderwysers benoem was, het die onderwys ook na die forte uitgebrei. Behalwe manskappe is ook mettertyd korporaals en onderoffisiere onderrig, terwyl 'n paar offisiere militêre onderwys aan toekomstige offisiere gegee het. ${ }^{40}$

Op 12.4.1898 is die onderwyser Heinrich Sebastiaan du Toit aan Steen toegevoeg en kon die garnisoen van Fort Klapperkop ook onderwys ontvang, terwyl die werk tussen die twee onderwysers verdeel is. In Februarie 1899 was Du Toit as onderwyser in die kamp werksaam en op 13.2.1899 het hy 'n versoek aan It-kol S.P.E. Trichardt gerig om as 2 It adj by die Lydende Artillerie aangestel te word. Tydens die oorlog is It Du Toit by Modderspruit gewond. Hy is na die Pretoriase Volkshospitaal vervoer waar hy 'n sestal operasies ondergaan het. Na byna vier maande was hy op 10.2.1900 nog in die genoemde hospitaal en het sy been, volgens sy eie verklaring, nog in 'n ellendige toestand verkeer. $^{41}$

In die jaarverslag oor 1898 is, met verwysing na inspekteursverslae, opgemerk dat onderrig gereeld in die kamp en die forte gegee is, terwyl die vertroue uitgespreek is dat, na die aanstelling van ' $n$ derde onderwyser, die onderwysresultate nog verder sou verbeter. Onderwys en die beoefening van die godsdiens het hand in hand gegaan. Op Sondae is kerkdienste bygewoon terwyl die een of ander leraar elke Dinsdagaand ' $n$ diens in die kamp gelei het. ${ }^{42}$

Op 31.1.1899 het onderwyser Steen gerapporteer dat die onderrig aan manskappe en toekomstige offisiere in die kamp en by die forte Schanskop en Klapperkop op 10.1.1899 hervat is. Aangesien die aantal diensdoende manskappe by Fort Klapperkop vergroot is, was daar ' $n$ dringende behoefte aan ' $n$ tafel en ' $n$ aantal banke. Steen het, in dieselfde verslag, daarop aangedring dat ' $n$ skoolgeboutjie by elkeen van die forte opgerig word en, in die verband verklaar: "Immers er wordt school gehouden in de eetkamer der manschappen en wel's morgens even na het ontbyt. Ik behoef niet te zeggen, dat het er 'minder frisch' is. Bovendien is het er donker, zyn er honderden vliegen en wordt de ruimte te klein, nu er $\pm 25-30$ personen geregeld van het onderwys kunnen gebruik maken." 43 
Volgens dieselfde verslag was die meeste artilleriste in standerds 1 en 2, sommiges in standerd 3 en 'n enkeling in standerd 4 . Oor die opkoms van die leerlinge was Steen nie tevrede nie en gevolglik het hy aan die hand gedoen om die manskappe van $16 \mathrm{~h} 30$ tot $19 \mathrm{~h} 00$ en die toekomstige offisiere van $14 \mathrm{~h} 00$ tot $16 \mathrm{~h} 00$ te onderrig.

Ten slotte het hy die aandag op die toename van die getal leerlinge by die forte gevestig, vermeld dat telegrafiste ook onderrig is en die aankoop van meer skoolbehoeftes dringend noodsaaklik geword het. ${ }^{44}$

In Februarie 1899 het It-kol S.P.E. Trichardt magtiging gevra om skoolmeubels, onder meer banke met dertig sitplekke, en leermiddels, soos 60 Psalm- en Gesangboekies, 30 woordeboekies, 50 lees- en 75 rekenboekies, 'n kaart van die Republiek en dies meer te kan aankoop. ${ }^{45}$

Die uitbreek van die oorlog het tot ontwrigting van die onderwys aan artilleriste gelei. In sy herinneringe vertel Steen dat hy onder kapt J.M.A. Wolmarans na Natal is om daar kommissariaatswerk te verrig. Saam met die burgers is hy terug na Pretoria, waar hy - na die Britse besetting van die hoofstad - geweier het om die eed van getroudheid aan die Britse bewind af te lê. Op 4.8.1900 is hy en sy gesin na sy geboorteland, Nederland, gedeporteer. ${ }^{46}$

Opleiding, met as 'n onderdeel die gesketste onderwys, wat in die volgende aanhaling die versamelnaam "opvoeding" omskryf is, het met as een van die middelpunte die Transvaalse Nederlandse Militêre Attaché by die Boeremagte, kapt jonkheer J.H. Ram, die Vereeniging ter beoefening van de Krygswetenschap oor die onderwerp "Enkele opmerkingen van krygskundigen aard naar aanleiding van den Zuid-Afrikaanschen Oorlog" toegespreek het. In die loop van sy toespraak het die spreker ondermeer verklaar: "Er staan hier twee systemen van opvoeding toegenover elkaar. By het Engelsche leger een opleidingsmethode en discipline, die verlammend werkte op alle rangen en het leger slechts geschikt maakte te handelen naar stereo-type regels en formules; die by de tegenparty - ik spreek hier over de Staatsartillerie der ZAR - een discipline en methode van opleiding gehoorzaamheid vorderende, doch wars was van alle strakke vormen, en die een groote ruimte liet aan het initiatief van den mindere. Dat het laatste systeem de voorkeur verdient, wie zal het betwyfelen na de verkregen ervaringen?"47
* Jan Ploeger (Kol aftr), MA, MEd, D Phil; oud SSO Argief en Navorsing, SAW; oud-Staatshistorikus, RSA.

\section{Aantekeninge}

1. S.P. Engelbrecht, J.A.I, Agar Hamilton, A.N. Pelzer en H.P.H. Behrens (red) Pretoria (1855-1955) Geskiedenis van die stad Pretoria (Pretoria, s.J.) p $86 \mathrm{ev}$.

2. W.J. de Kock en D.W. Krüger (red) Suid-Afrikaanse Biografiese Woordeboek (Kaapstad, Johannesburg, 1972), deel 2, pp 581-582.

3. J. Ploeger Die Fortifikasie van Pretoria. Fort Klapperkop. Gister en Vandag (Pretoria, 1968) verspreide bladsy ivm S.P.E. Trichardt: SuidAfrikaanse Biografiese Woordeboek, deel 2, pp 769-770.

4. TAB, UR 13, UR 14.2.1896, URB 122, met verwysing na R1423/96. Die toerier of fourier (fr) was 'n onderoffisier of 'n korporaal wat onder meer vir die verkryging van voer vir die perde, inkwartiering edm van die artilleriste te velde gesorg het.

5. Ibid., URB 243. Met verwysing na R3351/96 en EVR Not art 1573, 13.1.1896.

6. Ibid., SS 5805, p 110.

7. 0.J.O. Ferreira (teksversorger, edm), Geschiedenis Werken en Streven van S.P.E. Trichardt Luitenant Kolonel der vroegere Staats Artillerie ZAR (Pretoria, 1975) pp XII-XIX (met besonderhede oor T. en K.).

8. Ibid., $p 84$

9. Ibid., $\mathrm{p} 85$

10. TAB, SS 6189 , CR $842 / 97$ en bygevoegde dokumentasie.

11. O.J.O. Ferreira, tap., p 85.

12. TAB, SS 6189 , CR $842 / 97$, CR $696 / 97,1.2 .1897$; Kommandant-generaal Staatspresident, 6.2.1897.

13. Ibid., om CR $265 / 97$.

14. Ibid., CR 697/97, Offisiere Staatsartillerie - Kommandant-generaal, 4.2.1897, met bygevoegde aantekeninge edm.

15. Ibid

16. Ibid., CR 1394/97, 9.3.1897

17. Ibid., Lêeraantekening aan SS(B), 22.2.1897

18. Ibid., Lêeraantekning KG, 24.3.1897, met verwysing na die van 22.2.1897.

19. Ibid., Lêeraantekening KG, 22.4.1897.

20. TAB, KG 203/1, P.E. Erasmus. Kommandant-generaal. Ostorf by Schwerin, Duitsland, 21.10.1893.

21. TAB, Jaarrapport van den Commandant generaal over 1894, p 1. Ibid., oor $1896 \mathrm{p} 7$.

22. Ibid., Stukken betrekking hebbende op den inval van de troepen de British South Africa Company vir de Zuid-Afrikaansche Republiek (Groenboek, nr 2/1896) (Pretoria, 1896), p 6 iv. Met betrekking tot maj P.E. Erasmus is verder om die volgende bekend. Hy is tussen 20.4.1897 en 15.5.1897 getroud (KG 92/2, CR 1703/97). Op 11.2.1899 het It-kol S.P.E. Trichardt versoek dat aangesien kapt J.F. Wolmarans tot majoor bevorder is, maj Erasmus as Majoor Commandant der Vestingartillerie van die ZA Republiek aangestel word. Na sy bevordering sou maj Wolmarans die bevel oor die RA aanvaar. Aan hierdie versoek is niks gedoen nie (SS 7734, R 3034/99). Op 8.12.1899 het staatsprokureur J.C. Smuts van die hooflaer by Ladysmith getelegrafeer dat Lombardskop tydens die afgelope nag deur Britse troepe beset en 'n "Long Tom" en 'n houwitser met dinamiet beskadig is. Die ramp was, volgens die Staatsprokureur, aan nalatigheid van die burgerwag en die artilleriste te wyte. Op dieselfde dag het genl Louis Botha aan die Staatsekretaris getelegrafeer dat die twee kanonne onbruikbaar was. Op 12.12.1899 het genl Louis Botha aan die Staatsekretaris voorgestel dat die regering die skuldige, maj Erasmus, onmiddellik skors en dat hy sowel as It Malan, kmdt Weilbach en vk G. Meyer naderhand voor ' $n$ krygsraad verskyn. Op 14.12.1899 is die genoemdes geskors. 'n Krygsof militêre hof sou die aangeleentheid ondersoek maar tot op 15.2.1900 het dit nie geskied nie. Op die genoemde datum het die regering besluit om die genoemdes in hulle poste te herstel tot tyd en wyl die militêre hof uitspraak sou doen. Oor hierdie besluit het It-kol Trichardt hom vererg en op 3.4.1900 het hy van Brandsfort aan die Staatsekretaris geskryt dat om sonder sy aanbeveling as bevelhebber van die Staatsartillerie en sonder vryspraak deur 'n militêre hof maj Erasmus en 2 II Malan weer in hulle poste te herstel vir hom onverstaanbaar was. Hoe kon hy in die toekoms offisiere weens pligsversuim straf. lewers het hy op ondermyning van sy gesag gewys en die aandag gevestig op die blaam wat op sy korps rus. Aan hierdie uitlating het It-kol Trichard toegevoeg: "Om meer dan een rede wensch ik, dat majoor Erasmus en Luitenant Malan gedurende den oorlog niet weer in die gelederen de Artillerie in treden, daar de Artillerie zonder hen nu reeds byna 5 maanden klaar gekomen is en goed werk verricht heeft. (SS 8303, R 2373, diverse korrespondensie 8.12.1899-27.4.1900). Kyk verder L.S Amery (red) The Times History of the War in South Africa, deel 3, p 172 
deel 6, p 594 (Cordua). In die List of Burghers who have surrendered their arms in the Transvaal and Orange Free State (TAB) is maj P.E. Erasmus op p 23 vermeld.

In sy reeds genoemde gepubliseerde herinneringe verwys It-kol S.P.E. Trichardt op pp 126-127 na die sogenaamde kanoninsident en sy reaksie op die gebeurtenis, terwyl hy op p 167 vermeld dat hy, na oorleg met sy offisiere, oos van Pretoria, besluit het om aan genl Louis Botha voor te stel om majoor Erasmus te ontslaan omdat hy, na die Britse besetting van Pretoria, daar agter gebly het. Mbt kapt P.E. Erasmus se militêre loopbaan na 1912 is om bekend dat hy op 17.12.1914 as waarnemende distriksoffisier, 6 Militêre Distrik, benoem is.

23. SS 6189, Memorandum Kommandant-generaal - Staatsekretaris (B), 15.5.1897.

24. Ibid.

25. Ibid., Memorandum Staatsekretaris (B) - Kommandant-generaal, 15.5.1897; ibid., Memorandum Kommandant-generaal Staatsekretaris (B), 18.5.1897.

26. Ibid., Memorandum Staatsekretaris (B) - Kommandant-generaal, 16.6.1897.

27. Ibid., CR 3316/97, majoor P.E. Erasmus - Kommandant-generaal 19.6.1897.

28. Ibid.

29. Ibid., CR 3317/97, kapt P.J. van der Merwe ea - Kommandant-generaal, 19.6.1897. Die daarna genoemde datums berus op lêeraantekeninge en die aanstelling is as Goewermentskennisgewing nr 317 in die Staatskoerant (ZAR) van 14.7.1897 gepubliseer.

30. 0.J. Ferreira (teksversorger, edm), tap, p 85. Vir ondergeskikte korpslede was die volgende eed voorgeskryt: "Ik de ondergeteekende in myne hoedanigheid als lid van het Corps Staats Artillerie zweer plechtig trouw aan het volk dezer Republiek, alle boven my gestelde personen te zullen eerbiedigen, alle hunne bevelen te zullen uitvoeren en my stiptelyk te zullen gedragen overeenkomstig de wetten des Lands en naar de wet en regulatiën van het Corps. Zoo waarlyk helpe my God Almachtig." (KG die hooflaer op Rietvlei voor genl P.J. Joubert, kommandant-generaal, vise president en vrederegter, afgelê.)

31. 0.J.0. Ferreira, tap, $p 85$.
32. Staats Almanak voor de Zuid-Afrikaansche Republiek 1898 (Pretoria, 1897), p 43

33. Wet nr 1, 1896, afdeling 10 .

34. TAB, KG $68 / 3$, CR $2746 / 96$ kapt J.F. Wolmarans - Kommandant-generaal, 21.3.1896.

35. Ibid., KG 87.1, CR 63/97.

36. Ibid., SS 6102, p 178 (advertensie) ivm 'n eksamen vir offisiere. Die applikante (21-35 jaar) sou in die volgende vakke geeksamineer word: Nederlandse taal, vaderlandse en algemene geskiedenis, aardrykskunde, algebra, meetkunde, rekenkunde, fisika en artilleriewetenskappe.

37. Sy herinneringe is onder die opskrif "Herinneringen omtrent myn verblyf als onderwyzer in de ZA Republiek" in die Almanak van die Nederduitsch Hervormde Kerk van Afrika 1944, pp 67-86, gepubliseer (met foto). Mnr Steen is op 13.10.1964 in die ouderdom van ruim 98 jaar op Pretoria oorlede. Kyk ook KG, CR 3688/97 (OR 8563/97), 12.7.1897.

38. KG 108/1, CR 5387/97, L.L. Steen - It-kol Staatsartillerie, 7.10.1897; ibid., It-kol Staatsartillerie - Kommandant-generaal 4.10.1897.

39. De Volkstem, 16.10.1897. As sprekers het genl P.J. Joubert, maj P.E. Erasmus en dr N. Mansvelt opgetree. Kyk ook aant 37. L.L. Steen se herinneringe, $p 78$.

40. Steen se genoemde herinneringe, p 79. Kyk ook KG 109/2. CR 5664/97, 18.11.1897 (Steen kla oor toestand van skoolgebou): KG 114/1. CR 522/98, L.L. Steen - It-kol Staatsartillerie, 13.1.1898 (aa leermiddels vir Fort Schanskop aan).

41. KG 142/3. CR 762/99 (jaarverslag 1898), ibid., KG 486, p 358, H.S. du Toit - maj J.F. Wolmarans, 13.2.1899; SS 8371, It H.S. du Toit Staatsekretaris 10.2.1900. Kyk ook F.V. Engelenburg en G.S. Preller. Onze Krygs-officieren (Pretoria, 1907), p 210. Lt du Toit het herstel en is, ofskoon hy nog aan sy wond gely het, met die Staatsartillerie na die Hoëveld. Hy het tot die einde van die oorlog in die veld gebly.

42. KG 142/3. CR 762/99.

43. SS 7846, R 6819/99, 31.1.1899.

44. Ibid.

45. KG 144.2, CR 1279/99, 16.2.1899.

46. Steen se genoemde herinneringe, pp 83-84. Kyk ook KG 489, p 14. Skrywe van 1.5.1900

47. TAB, LA 982, Vereeniging ter beoefening van de krygswetenschap 1901-1902 ('s - Gravenhage, 1902), $3^{\mathrm{e}}$ verslag, pp 221-111. 